\title{
Releasable and Non-Releasable Capital Buffers in the European Union: From Puberty to Maturity
}

\author{
Katerina Lagaria ${ }^{1}$ \\ Bank of Greece
}

\begin{abstract}
The policy framework on the countercyclical capital buffer (CCyB) and the capital conservation buffer $(\mathrm{CCoB})$ is still in its early stages of implementation in the European Union (EU). Prior to the COVID-19 pandemic crisis, a general inaction bias prevailed among its Member States. The recent experience with emergency macroprudential relaxation measures in response to the pandemic shock highlighted the need for improved capital buffer usability. As the relevant framework heads towards a more mature phase, this paper discusses lessons learned from the use of buffers so far, recent findings regarding factors inhibiting their deployment and key suggestions on making the buffers fully usable in times of trouble, thus hoping to contribute to the macroprudential debate following the buffers' first stress event.
\end{abstract}

Keywords: macroprudential policy, countercyclical capital buffer, capital conservation buffer, procyclicality, bank capital requirements, Basel III, European Union

\section{INTRODUCTION}

Capital buffers and macroprudential oversight are two critical respects in which the banking sector's experience with the COVID-19 pandemic crisis has differed from previous financial stress episodes. Early lessons can be drawn from the use so far of a releasable, time-varying capital buffer, the countercyclical capital buffer (CCyB), and a static, non-releasable capital buffer, the capital conservation buffer (CCoB), both relative novelties in the financial regulatory framework by virtue of international standards adopted by the Basel Committee on Banking Supervision (BCBS) in the wake of the global financial crisis (GFC). This paper offers a detailed analysis of the international policy guidance on the CCyB and the CCoB and places special emphasis on the relevant policy framework in the European Union (EU), also applicable to countries of the European Economic Area (EEA). ${ }^{2}$ Stock is taken of the buffers' heterogeneous implementation in the EU/EEA and recent macroprudential relaxation measures in response to the COVID19 shock. The growing realization of the need for usable buffers along with a set of factors lately identified

as inhibiting their deployment are then discussed based on a selected review of relevant literature. Finally, a couple of key policy suggestions are examined in view of the post-pandemic transition of the two capital buffers towards a more mature phase. 


\section{INTERNATIONAL POLICY GUIDANCE ON THE CCOB AND THE CCYB}

\section{The Rationale Behind Basel III Capital Buffers}

Historically, rules governing banks, driven by similar forces to the ones that produce financial system procyclicality, have been found to be loosened in good times and tightened in bad times. The procyclicality of financial regulation (Goodhart, 2009) was one of the key issues brought to the fore by the global financial crisis (GFC). Under favorable economic conditions, credit grew excessively, fueling an unsustainable economic expansion, followed by an economic downturn which led to large losses in the banking sector and a credit crunch (as banks collectively reduced credit supply and tightened credit conditions), which exacerbated the economic downturn that then fed back on to the banking sector.

The experience of the GFC challenged some of the underlying assumptions about the nature of financial markets, leading to a newly formed consensus around the idea that procyclical practices inherent in the financial system had the potential to be reinforced by regulatory practices. Macroprudential policy was the "missing ingredient" (Bank of England, 2009), as competent supervisory authorities had been lacking the legal mandate and instruments to address systemic risk, defined as "the risk of disruptions to the provision of financial services caused by an impairment of all or parts of the financial system [that] can cause serious negative consequences for the real economy" (IMF, 2009).

Ex ante measures such as capital buffers are used before or as systemic vulnerabilities are building up to address the "time dimension" of systemic risk (see Table 1) and reduce reliance on ex post policy interventions in the event of a financial shock. In such an eventuality, capital buffers built through the cycle are released to improve the resilience of the banking sector via a direct effect on banks' loss-absorbing capacity and a reduction in the likelihood and severity of a systemic crisis (Aikman, Haldane \& Kapadia, 2013). The regulatory microprudential focus on the safety and soundness of individual institutions is also complemented by macroprudential tools geared towards addressing vulnerabilities from interconnectedness and the associated distribution of risk within the financial system at any given point in time ("crosssectional” dimension, see Table 1) (IMF-FSB-BIS, 2016).

TABLE 1

CRITICAL PHASES OF A FINANCIAL CYCLE

\begin{tabular}{|l|l|l|l|l|l|}
\hline Phase & $\begin{array}{l}\text { Type of } \\
\text { systemic } \\
\text { risks }\end{array}$ & $\begin{array}{l}\text { Measurement } \\
\text { focus }\end{array}$ & Dimension & $\begin{array}{l}\text { Examples of } \\
\text { vulnerabilities/ } \\
\text { externalities }\end{array}$ & $\begin{array}{l}\text { Modelling } \\
\text { approach }\end{array}$ \\
\hline Risk build-up & $\begin{array}{l}\text { Cyclical } \\
\text { risks }\end{array}$ & $\begin{array}{l}\text { Probability of } \\
\text { default }\end{array}$ & Time & $\begin{array}{l}\text { Asset-price } \\
\text { misalignment, excessive } \\
\text { leverage, maturity } \\
\text { mismatch }\end{array}$ & $\begin{array}{l}\text { Time series } \\
\text { models, early } \\
\text { warning } \\
\text { models, } \\
\text { market-based } \\
\text { indicators }\end{array}$ \\
\hline Amplification & $\begin{array}{l}\text { Contagion } \\
\text { and } \\
\text { spillovers }\end{array}$ & $\begin{array}{l}\text { Loss-given } \\
\text { default }\end{array}$ & $\begin{array}{l}\text { Cross- } \\
\text { sectional, } \\
\text { cross- } \\
\text { border }\end{array}$ & $\begin{array}{l}\text { Interconnectedness, } \\
\text { commonalities in } \\
\text { exposures }\end{array}$ & $\begin{array}{l}\text { Networks, } \\
\text { spillover } \\
\text { models, } \\
\text { conditional } \\
\text { loss } \\
\text { probabilities, } \\
\text { structural }\end{array}$ \\
\hline
\end{tabular}

Source: Constâncio, 2019, p. 27.

The Basel II Capital Accord (BCBS, 2006) was criticized for being ill-equipped to cope with deep, systemic financial crises and for having procyclical tendencies (Goodhart \& Segoviano, 2004; Heid, 2007; 
ECB, 2009). Countercyclical instruments were therefore required to amend the Basel II regulation "towards applying a countercyclical multiplier on required capital, so that banks do not need to build up as much capital when it is scarce as when it is abundant" (ECB, 2009, p. 150). In more detail, the Basel framework's minimum capital requirements were expanded by two broad-based capital buffers (i.e. applicable to all banks within a territorial jurisdiction), introduced by the Basel III Capital Accord (BCBS, 2011): a CCoB aimed at contributing to the conservation of capital and ensuring that individual banks remain solvent during a period of stress and a CCyB in order to "provide the banking system with an additional buffer of capital to protect it against potential future losses, when excess credit growth in the financial system as a whole is associated with an increase in system-wide risk" (BCBS, 2010, p. 16). Both the CCoB and the CCyB must be satisfied entirely with CET1 capital and they are both expressed as a percentage of a bank's total riskweighted assets.

The $\mathrm{CCoB}$ is established over and above the Basel III minimum capital requirements. It is extended by the $\mathrm{CCyB}$, a dynamic, cyclical macroprudential buffer geared towards financial stability throughout the cycle and subject to a more complex policy design. As its name indicates, it should be used countercyclically: activated and built up when authorities deem aggregate credit growth to be excessive and associated with the build-up of systemic risk. In normal times, when financial stability risks are subdued or when banks suffer unexpected losses in periods of stress, the CCyB is intended to be released to prevent any undue contraction in the supply of credit to the real economy.

Compared with the inflexible, non-cyclical $\mathrm{CCoB}$, which must always be fulfilled, the CCyB combines a rules-based component with a discretionary approach, i.e. a set of mandatory rules and disclosure requirements coupled with a degree of judgment in assessing the build-up of systemic risk and national discretion with regard to the way in which competent authorities make and explain their decisions on the CCyB rate, albeit guided by the standards laid down in the Basel III Capital Accord (BCBS, 2010, p. 7).

\section{The CCyB Buffer Guide}

Given the differences in economic, credit, and financial conditions across BCBS jurisdictions, the Basel III Capital Accord sets out a policy stance for the CCyB that is not formally binding. Its rules-based component, the "buffer guide", must be complemented with a comprehensive risk assessment on the part of national authorities. Member States are required to adopt an "internationally consistent buffer guide" based on a reference benchmark for the CCyB calculation, the credit-to-GDP ratio, for which the BCBS (2010) recommends using a broad measure of nominal credit that captures all sources of debt funding to the domestic private non-financial sector. ${ }^{3}$

A standard methodology to calculate the parameters of the buffer guide is outlined: first of all, the ratio of the (nominal) broad credit in the private sector to the (nominal) gross domestic product (GDP) is calculated for each quarter. According to the BCBS methodology, the GDP is calculated as a four-quarter moving sum of GDP:

$\mathrm{GDP}=\mathrm{GDP} t+\mathrm{GDP} t-1+\mathrm{GDP} t-2+\mathrm{GDP} t-3$

The credit-to-GDP ratio in period $t$ for each Member State is calculated as:

$\mathrm{RATIO}_{t}=\frac{\mathrm{CREDIT}_{t}}{\mathrm{GDP}_{t}} \times 100 \%$

Secondly, the actual credit-to-GDP ratio is compared to its long-term trend, calculated using a onesided Hodrick-Prescott filter, ${ }^{4}$ whereby the smoothing parameter $\lambda$ is set at 400,000 . Hence, a measure of the credit-to-GDP gap is proposed as the deviation of the current credit-to-GDP ratio from its long-term trend, calculated in percentage points. The credit-to-GDP gap in period $t$ for each country is calculated as:

$\mathrm{GAP}_{t}=\mathrm{RATIO}_{t}-\mathrm{TREND}_{t}$ 
If the credit-to-GDP ratio is significantly above its trend, it might indicate potential credit growth. Being credit-based, the credit-to-GDP gap has the significant advantage that it appeals directly to the objective of the $\mathrm{CCyB}$, which is to achieve the broader macroprudential goal of protecting the banking sector from periods of excess credit growth. It has been chosen for its good performance as an early warning of banking crises: "The gap between the ratio of credit to GDP and its long-term backward-looking trend performs best as an indicator for the accumulation of capital, because this variable captures the build-up of system-wide vulnerabilities that typically lead to banking crises" (Drehmann, Borio \& Tsatsaronis, 2011, p. 189).

By way of example, a linear function has been proposed by the BCBS for mapping the relationship between the credit-to-GDP gap and the CCyB rate, whereby various levels of the credit-to-GDP ratio work as automatic trigger points for buffer increases (see Figure 1). In more detail, the BCBS recommends activating the $\mathrm{CCyB}$ when the credit-to-GDP gap breaches a threshold of 2 percentage points and continuing to increase it until a specified maximum buffer rate is reached (i.e. $2.5 \%$ ).

\section{FIGURE 1 \\ LINEAR RELATIONSHIP BETWEEN BUFFER GUIDE AND CREDIT-TO-GDP GAP ACCORDING TO THE BCBS STANDARDISED APPROACH}

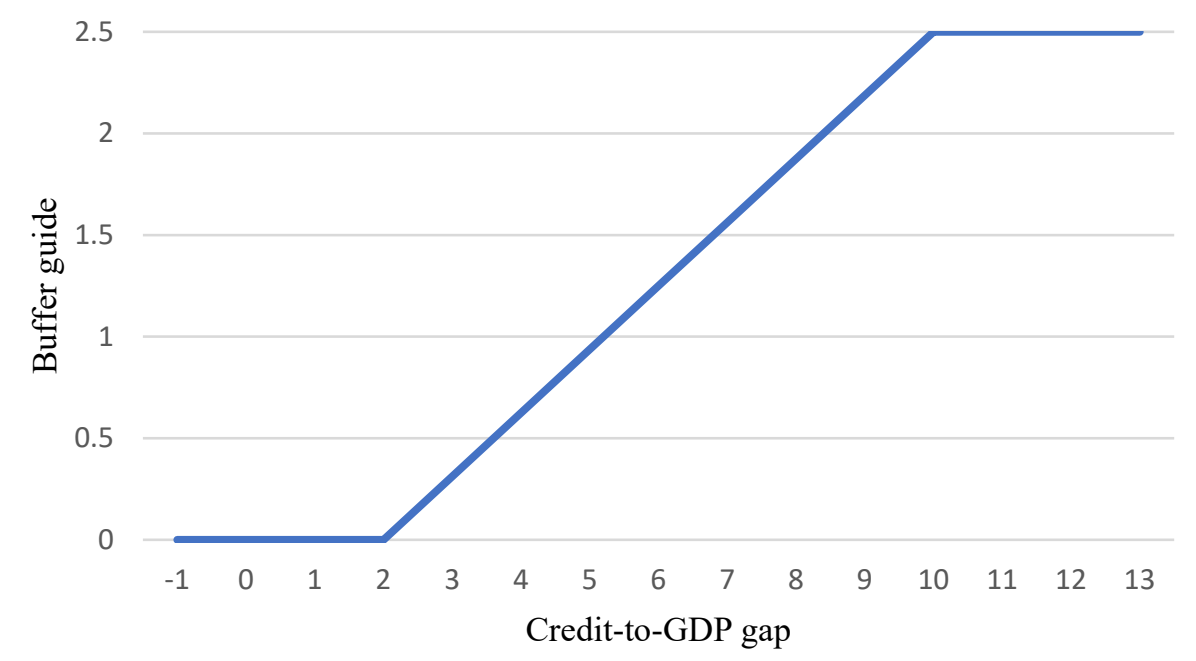

Source: Graphic representation of illustrative numerical values for the CCyB buffer guide and credit-to-GDP gap that are provided in BCBS, 2010, Annex 1, pp. 13-14. See also, by way of indication, Finansinspektionen, 2014, p. 14, and Deutsche Bundesbank, 2015, p. 14.

The calculation should ensure that account is taken of financial and macroeconomic conditions in each jurisdiction, as the buffer guide does not work well in all jurisdictions at all times. Hence, the credit-toGDP gap is to be used as a common starting reference point, rather than as the dominant parameter in relevant decision-making. National authorities must apply expert judgment in setting the buffer on a jurisdictional basis, using the best information available to gauge the build-up of systemic risks that signal the need to activate the CCyB (BCBS, 2010, p. 2). Such judgment should be firmly anchored in five principles: objective, buffer guide, risk of misleading signals, prompt release of the buffer, and other macroprudential instruments. In particular, the BCBS (2010) warns about the risk of misleading signals by the credit-to-GDP gap and suggests also considering other useful indicators for the CCyB, such as asset prices and real GDP growth, as well as operationalizing other macroprudential instruments.

\section{Buffer Range, Default Setting and Jurisdictional Reciprocity}

The Basel III framework recommends setting the CCyB within a specified range, allowing it to vary between $0 \%$ and $2.5 \%$ of total risk-weighted assets (at consolidated level), but also enabling buffers in 
excess of $2.5 \%$ if national authorities deem them appropriate in their national context. Although originally envisaging zero $\mathrm{CCyB}$ rates for most of the cycle and only activating or raising the buffer when systemic vulnerabilities were heightened, the Basel III policy guidance does not seem to rule out a non-zero (positive) default rate in order to strike the right balance between accurately pointing to credit crises and not sending misleading signals (Stojkov, 2020, p. 115). Authorities are expected to comply with automatic trigger points and take macroprudential action to raise $\mathrm{CCyB}$ rates, otherwise explain the information used and how it has been taken into account towards failing to take action or deviating from the suggested CCyB level ('comply or explain' approach).

An important feature of the CCyB's international policy design is the automatic mandatory "jurisdictional reciprocity" for CCyB rates up to $2.5 \%$, which is intended to minimize the degree of crossborder spillovers and regulatory arbitrage opportunities ${ }^{5}$ and keep a level playing field between domestic banks and foreign banks. ${ }^{6}$ Reciprocity means that credit exposures to a private sector entity located in any given jurisdiction are under the same $\mathrm{CCyB}$ requirement, irrespective of the country of the bank which provides credit. A national authority that activates the buffer in a jurisdiction is expected to promptly inform its foreign counterparts. In turn, authorities in other jurisdictions should require their banks to apply the buffer for exposures in that jurisdiction. The bank-specific CCyB rate is calculated as the weighted average of CCyB rates set by the jurisdictions where the bank has relevant exposures.

\section{THE EU POLICY FRAMEWORK ON THE CCOB AND THE CCYB}

\section{The Combined Buffer Requirement (CBR)}

The CCyB and the CCoB have been fully operational in the EU since 1 January 2019. They form part of the Combined Buffer Requirement (CBR), which is made up of the total CET1 capital that is necessary to meet the requirement for the $\mathrm{CCoB}$ extended with the $\mathrm{CCyB}$ rate, and the systemic risk buffer (SyRB) cumulative with the higher of the systemic-related buffer rates, i.e. the buffer on global systemically important institutions (G-SII buffer) and the buffer for other systemically important institutions (O-SII buffer), in cases where a group is subject on a consolidated basis to both a G-SII buffer and an O-SII buffer.

$C B R=(C C o B+C C y B+S y R B+\max \{O-S I I, G-S I I\})$

In accordance with the Basel III international standards, a breach of the CBR automatically triggers restrictions on capital distributions such as dividend payments, share buybacks, payments on Additional Tier 1 (AT1) instruments, as well as variable staff bonuses or discretionary pension benefits. In other words, a violation of the $\mathrm{CCoB}$ and $\mathrm{CCyB}$ requirements may trigger restrictions on the award of variable remuneration which is tied with the profit situation of a given bank during any period in which the CBR is not met, taking into account the long-term health of the bank. The restrictions are imposed in order for the earnings that would otherwise have been paid out to be retained by the banks, thus providing an additional capital cushion that can be drawn down in the event of declines in bank asset values. Their objective is to prevent the "imprudent outlay of capital resources and ensure that banks rebuild their capital strength in a timely and organic manner" (Hernández de Cos, 2019) shown to be beneficial during normal times and amidst financial crises, but harmful during recoveries (Schroth, 2021).

Under the provisions of the fifth Capital Requirements Directive (Directive (EU) 2019/878, hereafter CRD V), if a bank's own funds do not meet the CBR, the bank can make distributions only within the limits of a Maximum Distributable Amount (MDA). A capital conservation plan must be submitted to the national competent authority setting out the MDA, providing estimates of income and expenditure and a forecast balance sheet, measures to increase the capital ratios of the firm and a plan and timeframe for increasing capital in order to meet the CBR.

The MDA is calculated by the bank as the product of $60 \%, 40 \%, 20 \%$ or $0 \%$ (depending on which quartile (from highest to lowest) of the CBR the bank is in) of the sum of interim and year-end profits that are not included in CET1 capital (minus amounts which would be payable by tax if profits were to be retained). The restrictions become more stringent, the more the buffer is eroded, in order to prevent the 
institution from further eating into its capital and ensuring that it restores its capital levels when operating within the buffer range. For instance, a $0 \%$ MDA restriction means setting the portion of earnings that may be distributed to zero in the case of a bank that has exhausted its CBR.

The use of capital buffers providing an additional layer of loss-absorbing resources on top of the regulatory minimum follows a specific hierarchical order from top to bottom (see Figure 2): as a first line of defense, a bank may run down its voluntary buffers (also known as management buffers) and Pillar 2 Guidance (P2G). The CBR and its constituent elements may provide a second line of defense in periods of stress to absorb unexpected losses subject to automatic distribution restrictions aimed at maintaining capital above the absolute minimum.

\section{FIGURE 2 \\ THE COMBINED BUFFER REQUIREMENT IN BANKS' CAPITAL STACK}

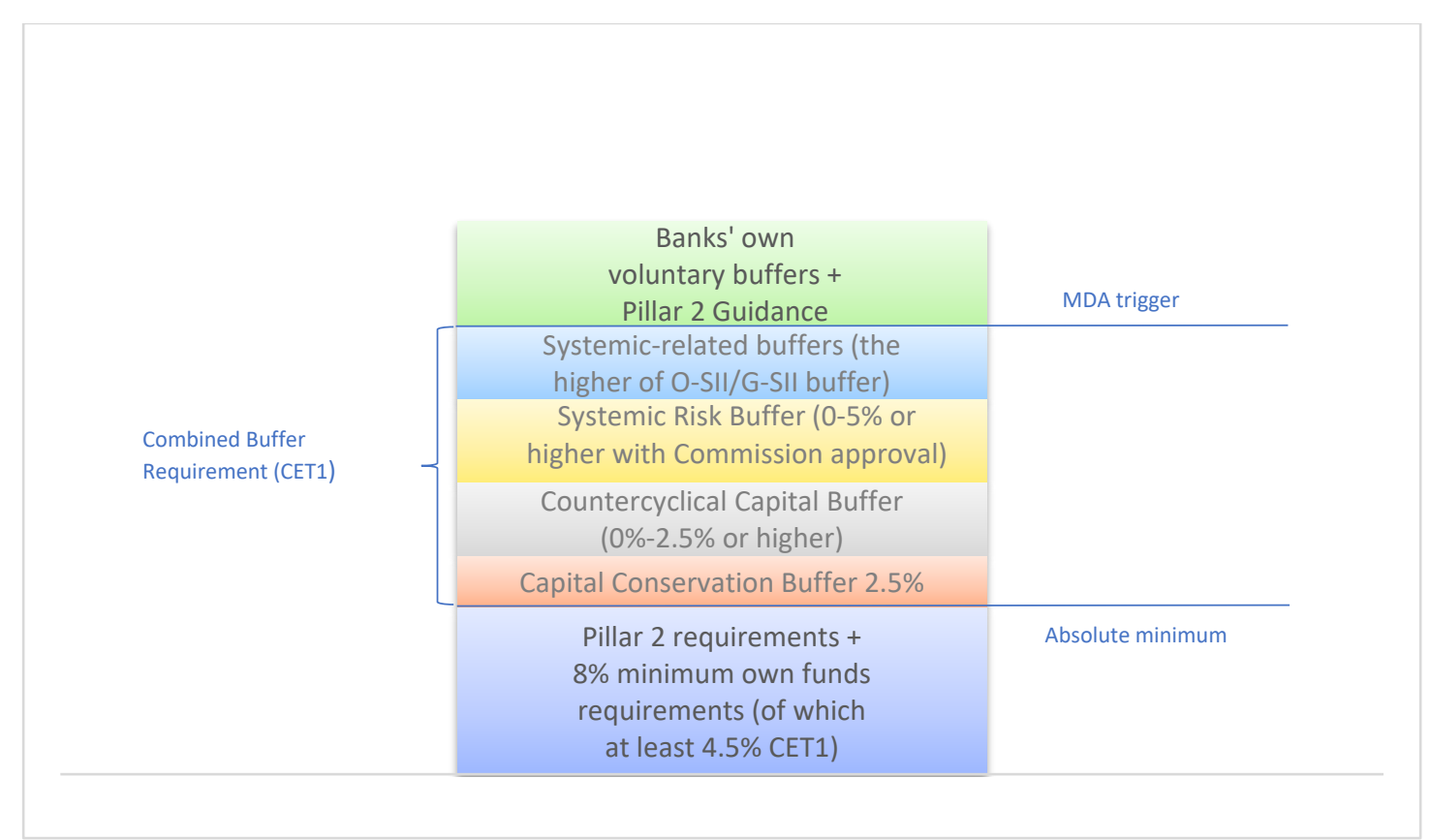

Source: Author's elaboration based on European Systemic Risk Board (ESRB), 2015, p. 20.

Note: Expressed as percentages of the total risk exposure amount.

The intended use of the EU macroprudential toolkit has been for the fixed CCoB rate to be complemented by risk-weighted additional structural buffers, as well as cyclical buffers such as the CCyB, which may be released in periods of stress or when cyclical systemic risks recede (see Figure 3). The CCyB's main focus is on the downturn period: it aims at improving banks' resilience to financial systemic shocks, so that they can sustain a smooth flow of credit to the real economy. In the upward phase, it may help towards mitigating the build-up of risk by keeping a lid on (excessive) credit growth as a secondary side effect. It thus serves the broad macroprudential objective of enhancing the financial system's resilience to shocks and the ancillary objective of "leaning against the wind, [i.e.] reducing the amplitude of the financial cycle, thereby limiting the risk of financial distress in the first place" (Crockett, 2000). Two issues are raised by this secondary objective: first, the need to identify the financial cycle and then ask what amplitude would be "small enough". In both cases, it is uncertain what level of confidence is actually achievable (Committee on the Global Financial System, 2010, p. 7). 
FIGURE 3

\section{STYLISED REPRESENTATION OF THE CCYB'S USE THROUGH THE FINANCIAL CYCLE}

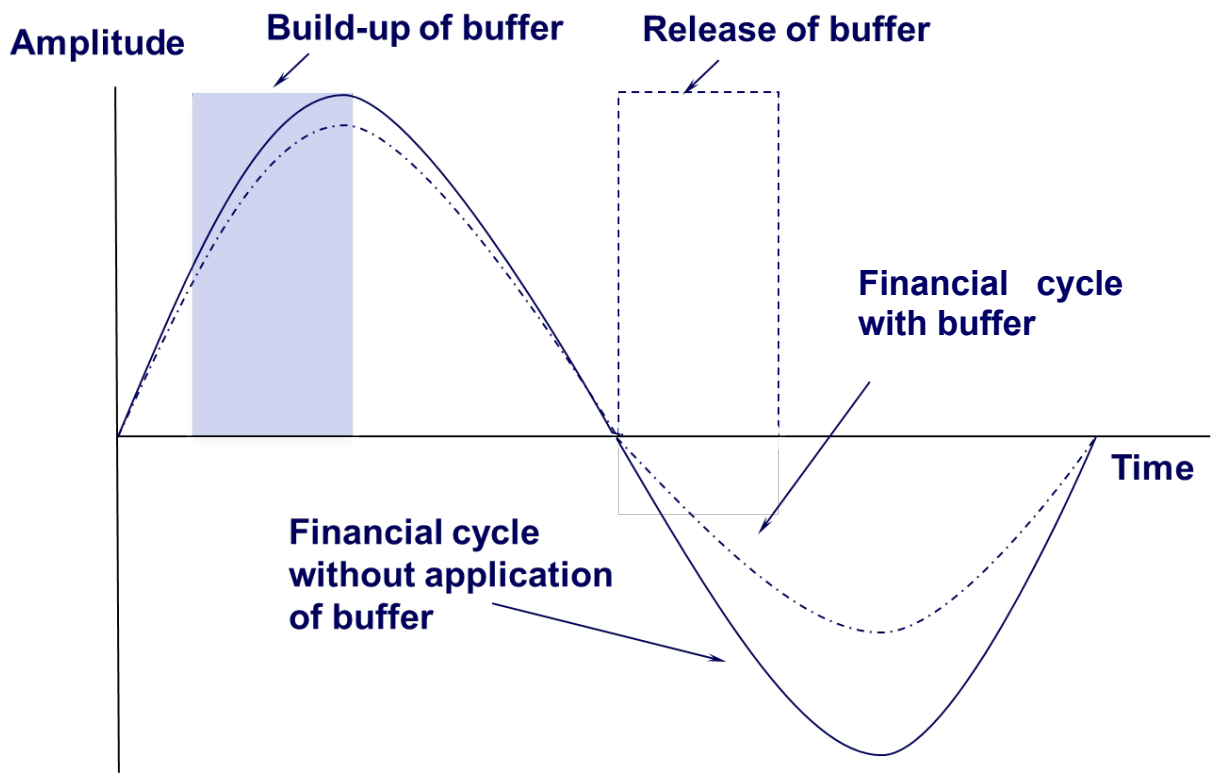

Source: ESRB, 2014, p. 12.

Under the EU regulatory framework, institutions ${ }^{7}$ (i.e. all banks and certain types of investment firms) must maintain an "institution-specific CCyB" consisting of the weighted average of the domestic and foreign CCyB rates that apply in the countries where the institution's relevant credit exposures are located. Reciprocity is mandatory for buffer rates up to $2.5 \%$ and voluntary for CCyB rates exceeding $2.5 \%$. The legal process for reciprocation in the EU is initiated by the activating Member State which sets an institution-level 'maximum materiality threshold' when asking for reciprocation, in line with the guiding principles on the calibration of the threshold level, a common materiality indicator, a first initial orientation value and methodological principles regarding the final decision laid down at European level (ESRB, 2015, pp. 248-250). The rationale is that cross-border financial activity can undermine the effectiveness of national macroprudential policy. A domestic CCyB rate may be less effective as a result of regulatory arbitrage if it is not fully recognized by the national authorities of institutions with relevant credit exposures (ESRB, 2015, p. 32). As far as third-country CCyB rates are concerned, EU Member States may set different buffer rates to those set by a third-country authority for a third country, for the purposes of the calculation by domestically authorized institution of their institution-specific CCyB rates, subject to central guidance on uniform recognition across the EU/EEA by the European Systemic Risk Board (ESRB).

\section{The EU Policy Framework on the CCoB}

Given its entirely rules-based nature, the EU policy framework on the $\mathrm{CCoB}$ is rather straightforward. The $\mathrm{CCoB}$ is a non-cyclical capital requirement set at the international level (by means of the Basel III standards) which can be used to provide relief in times of stress. As indicated by its name, it aims to conserve banks' capital in line with a set of fixed rules (percentage), which must always be complied with, in addition to the hard, non-cyclical minimum capital requirements (currently set at $4.5 \%$ in terms of CET1 and $8 \%$ in terms of total capital) that must be met under all circumstances under Article 92(1) of the Capital Requirements Regulation (Regulation (EU) No 575/2013, hereafter CRR).

As laid down in the Basel-compliant EU legislative framework, the CCoB must be met only with CET1 capital equal to $2.5 \%$ of an institution's total risk exposure amount (TREA) to ensure that an additional layer of capital can be drawn down in the event of unexpected losses. The CCoB calculation uses the TREA as the denominator. 
$C C O B=\frac{C E T 1}{T R E A}=2.5 \%$

Together with the minimum CET1 "own funds requirement" they comprise the 'core requirement' for CET1 capital (i.e. the $4.5 \%$ minimum CET1 requirement plus the $2.5 \%$ capital conservation buffer) set for all EU Member States, which is regulatorily fixed and cannot be adjusted over time at the discretion of national authorities. If a bank dips into its $\mathrm{CCoB}$, restrictions are automatically triggered on capital distributions and variable remuneration.

The CCoB was phased in over a four-year period in the EU (see Table 2), beginning at the rate of $0.625 \%$ of an institution's risk-weighted assets (RWAs) on 1 January 2016 and increasing each subsequent year by an additional 0.625 percentage points, to reach the predetermined level of $2.5 \%$ of RWAs. Since 1 January 2019, all EU Member States require institutions to maintain a CCoB of $2.5 \%$.

\section{TABLE 2 \\ CCOB PHASE-IN UNDER BASEL III}

\begin{tabular}{|l|l|}
\hline $0.625 \%$ of risk-weighted assets & 1 January 2016 \\
\hline $1.25 \%$ of risk-weighted assets & 1 January 2017 \\
\hline $1.875 \%$ of risk-weighted assets & 1 January 2018 \\
\hline $2.5 \%$ of risk-weighted assets & 1 January 2019 \\
\hline
\end{tabular}

Source: Based on BCBS, 2011, p. 57.

\section{The EU Policy Framework on the CCyB}

The EU has elaborated a well-defined policy and operational framework for the application of the CCyB. The CET1-only CCyB requirement is set at Member-State level, as national authorities have the discretion to vary the $\mathrm{CCyB}$ rate up and down through the cycle in line with their assessment of the risk, at system level, that banks will incur losses.

The 'guided discretion' approach, which combines national authorities' expert judgment with a rulesbased common starting point, is the centerpiece of the EU framework on the CCyB's operationalization (ESRB, 2015, pp. 43-44). Member States are granted considerable flexibility to design and apply their own policy frameworks and practices reflecting the specificities of their economies and financial systems, the differences in their economic, financial and credit cycles, and the varying availability of data (e.g. historical data and stress tests) in their jurisdictions. As a result, CCyB regimes are heterogeneous across countries, but must comply with rules on jurisdictional reciprocity.

The CCyB may be set in the range between $0 \%$ and $2.5 \%$ of the TREA, calibrated in steps of 0.25 percentage points or multiples thereof. If deemed appropriate, national authorities have the discretion to impose a buffer above $2.5 \%$ of the TREA, as the maximum CCyB rate is open-ended.

An implementation lag applies when the $\mathrm{CCyB}$ is initially activated or adjusted upwards. An increase in the CCyB rate typically enters into application "no later than twelve months" from the date of its preannouncement (under Article 136(5) of Directive 2013/36/EU, hereafter CRD IV), but a shorter lead time is possible if justified on the basis of exceptional circumstances. By contrast, any decision to lower/release the $\mathrm{CCyB}$ rate can be made effective immediately after its announcement. There are two situations in which the buffer is reduced: i) when a severe shock or crisis necessitates the prompt release of capital, in which case the decision to reduce/release the CCyB swiftly may give banks the necessary capital space to absorb losses and support lending to the real economy; ii) in circumstances other than stress, when the financial cycle turns and risks to banks' resilience subside, the buffer may be gradually reduced. In both cases, the national authority must concurrently adopt a non-binding decision regarding the indicative period during which no increase in the domestic $\mathrm{CCyB}$ rate should be expected.

An institution-specific CCyB rate consists of the weighted average of the CCyB rates that apply in the countries where the institution's credit exposures are located. It has been designed to account for an 
institution's domestic authorization as a 'European passport' to provide financial services or establish branches across the EU/EEA subject to home Member State supervision.

A mandatory reciprocity mechanism for $\mathrm{CCyB}$ rates up to $2.5 \%$ requires an institution to apply the $\mathrm{CCyB}$ rate of the country in which the credit exposures are located, irrespective of the institution's location. By way of exception, if trading book exposures or foreign credit exposures represent less than $2 \%$ of an institution's aggregate risk-weighted exposures, the institution may choose to allocate these exposures to its home jurisdiction for the purpose of calculating the institution-specific CCyB rate.

The ratio of the total own funds requirements for credit risk that relates to the institution's relevant credit exposures in a given jurisdiction to the total own funds requirements for credit risk that relates to all of its relevant credit exposures is multiplied with the given jurisdiction's applicable CCyB rate. An indicative formula for the calculation of an institution-specific CCyB $(i C C y B)$ in the case of an institution with relevant credit exposures in three countries would be:

$i C C y B=\sum\left\{\left\lfloor\left(\frac{x}{x+y+z}\right) \times C C y B_{A}\right\rfloor+\left\lfloor\left(\frac{y}{x+y+z}\right) \times C \operatorname{CCy} B_{B}\right\rfloor+\left\lfloor\left(\frac{z}{x+y+z}\right) \times \operatorname{CCy} B_{C}\right\rfloor\right\}$

where:

\begin{tabular}{|l|l|l|l|}
\hline Jurisdiction & $\begin{array}{l}\text { Total own funds } \\
\text { requirements for credit } \\
\text { risk that relates to the } \\
\text { institution's relevant } \\
\text { credit exposures in the } \\
\text { given jurisdiction }\end{array}$ & $\begin{array}{l}\text { Applicable CCyB rate } \\
\text { in the given jurisdiction }\end{array}$ & $\begin{array}{l}\text { Total own funds } \\
\text { requirements for credit } \\
\text { risk that relates to all of } \\
\text { the institution's } \\
\text { relevant credit } \\
\text { exposures }\end{array}$ \\
\hline Country A & $\mathrm{x}$ & $\mathrm{CCyB}_{\mathrm{A}}$ & $\Sigma(\mathrm{x}+\mathrm{y}+\mathrm{z})$ \\
\hline Country B & $\mathrm{y}$ & $\mathrm{CCyB}_{\mathrm{B}}$ & $\Sigma(\mathrm{x}+\mathrm{y}+\mathrm{z})$ \\
\hline Country $\mathrm{C}$ & $\mathrm{z}$ & $\mathrm{CCyB}_{\mathrm{C}}$ & $\Sigma(\mathrm{x}+\mathrm{y}+\mathrm{z})$ \\
\hline
\end{tabular}

\section{HETEROGENEITY OF CAPITAL BUFFER IMPLEMENTATION IN THE EU/EEA}

In the heterogeneous setting of the EU/EEA, the nationally calibrated CCyB rate, deployed at the discretion of Member State authorities through the cycle, offers them the flexibility to adopt the policy approaches that best reflect the characteristics and specific situation of their financial systems, their economic situation, as well as data availability. As a result, national CCyB regimes and practices vary in terms of, inter alia, governance structures, reliance on the buffer guide, as well as the number and type of supporting indicators used and publicly communicated (analyzed below). Cross-country differences may be partly explained by the substantial variation across economic, financial and credit cycles in the EU/EEA. In particular, financial cycles in the EU have been found to be more correlated during stress times than in boom periods (Stremmel, 2015). As a result, Member States may be more often facing different types of systemic risk.

As regards the inflexible, non-cyclical $\mathrm{CCoB}$, the applicable legislative provisions and institutional arrangements provide for an EU-wide harmonized buffer rate, which has to be fulfilled at all times. However, diverse interpretations across EU Member States of the provisions on additional capital requirements and how they position themselves in relation to the minimum own funds requirement and the CBR have resulted in substantially different amounts of capital requirements imposed on individual banks in the EU and also different trigger points for automatic distribution restrictions (known as MDA triggers). The recently enacted revision of the EU framework on capital buffers by means of the CRD V and the second Capital Requirements Regulation (Regulation (EU) 2019/876, hereafter CRR2) has sought to clarify the relation between different elements of the capital stack in order to avoid such different interpretations resulting in different MDA triggers across the EU. 


\section{Macroprudential Governance Structures in the EU/EEA}

The heterogeneity of EU/EEA financial systems is primarily reflected in national macroprudential governance structures. Member States retain a leading role in initiating and implementing macroprudential measures in the EU/EEA, given their expertise with regard to the domestic banking system and deep understanding of the structural features of their respective financial systems. To this end, each Member State has appointed an authority in charge of identifying, monitoring, assessing, preventing and mitigating systemic risks ("macroprudential authority" established in accordance with Recommendation ESRB/2011/3) and an authority specifically responsible for setting the CCyB rate for that Member State ("designated authority" under Article 136 CRD IV). In most cases, the two converge into a single authority and, as a standard rule, institutional responsibility for setting the CCyB lies with the central bank's board of governors (see Table 3), like in the US. Such allocation of powers is all the more important given recent research findings showing that strong governance structures for the implementation of macroprudential policies and clear accountability for the CCyB significantly affect its use (Edge \& Liang, 2020).

\section{TABLE 3 \\ INSTITUTIONAL RESPONSIBILITY FOR (i) MONITORING SYSTEMIC RISKS AND (ii) SETTING THE CCYB RATE IN EU/EEA COUNTRIES}

\begin{tabular}{|c|c|}
\hline Single authority for both (i) and (ii) & Multiple authorities \\
\hline Belgium (central bank) & $\begin{array}{l}\text { Austria (i) Financial Market Stability Board and (ii) } \\
\text { Financial Market Authority }\end{array}$ \\
\hline Cyprus (central bank) & $\begin{array}{l}\text { Bulgaria (i) Financial Stability Advisory Council } \\
\text { and (ii) central bank }\end{array}$ \\
\hline Czech Republic (central bank) & $\begin{array}{l}\text { Croatia (i) Financial Stability Council and (ii) } \\
\text { central bank }\end{array}$ \\
\hline Estonia (central bank) & $\begin{array}{l}\text { Denmark (i) Systemic Risk Council and (ii) } \\
\text { Minister for Industry, Business and Financial } \\
\text { Affairs }\end{array}$ \\
\hline Finland (Financial Supervisory Authority) & $\begin{array}{l}\text { Germany (i) Financial Stability Committee (ii) } \\
\text { Financial Supervisory Authority }\end{array}$ \\
\hline France (High Council for Financial Stability) & $\begin{array}{l}\text { Italy (i) Macroprudential Policy Committee and (ii) } \\
\text { central bank }\end{array}$ \\
\hline Greece (central bank) & $\begin{array}{l}\text { Latvia (i) central bank and (ii) Financial and } \\
\text { Capital Market Commission }\end{array}$ \\
\hline Hungary (central bank) & $\begin{array}{l}\text { Luxembourg (i) Systemic Risk Committee and (ii) } \\
\text { Financial Supervisory Authority }\end{array}$ \\
\hline Iceland (Financial Stability Council) & $\begin{array}{l}\text { Netherlands (i) Financial Stability Committee and } \\
\text { (ii) central bank }\end{array}$ \\
\hline Ireland (central bank) & $\begin{array}{l}\text { Poland (i) Financial Stability Committee and (ii) } \\
\text { Minister of Finance }\end{array}$ \\
\hline $\begin{array}{l}\text { Liechtenstein (Financial Stability Council due to the } \\
\text { absence of a central bank) }\end{array}$ & $\begin{array}{l}\text { Slovenia (i) Financial Stability Board and (ii) } \\
\text { central bank }\end{array}$ \\
\hline Lithuania (central bank) & $\begin{array}{l}\text { Spain (i) [not yet officially established] (ii) central } \\
\text { bank }\end{array}$ \\
\hline \multicolumn{2}{|l|}{ Malta (central bank) } \\
\hline \multicolumn{2}{|l|}{ Norway (Ministry of Finance) } \\
\hline \multicolumn{2}{|l|}{ Portugal (central bank) } \\
\hline \multicolumn{2}{|l|}{$\begin{array}{l}\text { Romania (National Committee for Macroprudential } \\
\text { Oversight) }\end{array}$} \\
\hline \multicolumn{2}{|l|}{ Slovakia (central bank) } \\
\hline Sweden (Financial Supervisory Authority) & \\
\hline
\end{tabular}


The European Central Bank (ECB) is notified in the CCyB rate-setting process, as it is jointly responsible with national authorities for macroprudential policy in the area of the Single Supervisory Mechanism (SSM) ${ }^{8}$ Its role is to assess the national CCyB rate decisions and, if need be, decide to apply higher CCyB rates than those applied by Member States. Unused so far, the ECB's 'topping-up power' was promoted as a means to limit the scope for the natural bias towards inaction of national authorities, inherent in macroprudential policy (Schammo, 2019).

The 'inaction bias' on the part of national authorities may be attributed to the clearly visible short-term costs on banks of applying a dynamic macroprudential tool compared with the less discernible long-term gains of mitigating systemic risks successfully and achieving stable economic growth, which are difficult to measure and may affect different entities. In order to counter this 'inaction bias', a rules-based framework was put in place requiring national authorities to explain decisions to the ESRB, the EU-wide macroprudential body responsible for the oversight of the EU financial system as a whole.

\section{Reliance on the CСyB Buffer Guide and Expert Judgment}

The "guided discretion" approach caters for heterogeneous implementation of the CCyB across the EU. National authorities have the flexibility to decide whether to activate the CCyB, when to activate it and at what level, whether to raise/lower it after initial activation or to release it fully in periods of stress and rapidly weakening credit conditions. The basis for such decisions is an assessment of the level of systemic risk in the country concerned. This approach is designed to reflect specific national circumstances, but decision-making must follow centralized ESRB advice.

Decisions on setting the appropriate $\mathrm{CCyB}$ rate take into account a buffer guide which is consistent with the BCBS recommended approach and the ESRB's own guidance (ESRB, 2014), calculated by the national authority on a quarterly basis as a reference underpinning its $\mathrm{CCyB}$ decisions. Intended only as a common benchmark across the EU, it leaves plenty of room for national authorities to make a comprehensive risk assessment using a range of additional (quantitative and qualitative) indicators of credit growth and systemic risk, which is then combined with their expert judgment.

The ESRB (2014, pp. 41-42) recommends the overarching principles that should guide national authorities in exercising judgment as to the appropriate $\mathrm{CCyB}$ rate for their jurisdiction. Five of these principles are derived from the relevant BCBS guidance (2010) and two are specific to the EU level (i.e. communication and reciprocity). The ESRB also provides general guidance on the measurement and calculation of the credit-to-GDP gap and the calculation of buffer guides, but also on other variables that may complement the credit-to-GDP gap for signaling the build-up of system-wide risks associated with periods of excessive credit growth in the financial system (ESRB, 2015, pp. 6-7). No single calibration approach for the $\mathrm{CCyB}$ rate is advocated at EU/EEA level. Relevant guidance has been derived from Detken et al. (2014) investigating a number of alternative calculations and the credit-to-GDP gap in order to reduce the incidence of misleading assessments (ESRB, 2015, p. 38).

As far as identifying a reduction in cyclical risk, all national frameworks provide for a prompt $\mathrm{CCyB}$ release in a severe crisis, but very few clearly outline scenarios in the event of a gradual decline in systemic vulnerabilities, for which practical experience is still lacking (Arbatli-Saxegaard \& Muneer, 2020, p. 10). Such a gradual intervention requires a complex analysis of the domestic financial system's condition and the ESRB highlights in its relevant guidance that "even more than in the build-up phase, judgment may need to play an even greater role in identifying the appropriate timing for releasing the buffer" (ESRB, 2014, p. 41). By way of indication, the Hungarian central bank has laid down a set of rules governing a gradual release of the $\mathrm{CCyB}$ when cyclical systemic risks are on a steadily declining path to address two types of possible mistakes: a premature or an erroneous release of the CCyB rate (Magyar Nemzeti Bank, 2016). The Norwegian central bank follows an asymmetric approach to CCyB release, emphasizing that the $\mathrm{CCyB}$ should not be reduced automatically even if there are signs that financial imbalances are receding (Norges Bank, 2021). 


\section{Use of Additional Indicators}

National authorities are free to use additional supporting indicators in their CCyB calibration approaches, guided by empirical data on financial cycle and stress episodes at national level, also relying on market intelligence supervisory assessments and stress tests. The latter's advantages are that they are forward-looking, they can cover various scenarios and are thus valuable for assessing specific systemic vulnerabilities, but when the range of scenarios is more open, they are less useful in identifying risks (BIS, 2018).

Member States publish their CCyB rate-setting frameworks building on the ESRB's pre-identified list of indicators, aimed at credible $\mathrm{CCyB}$ decisions and coordinated market expectations. Two sets of indicators are recommended for assessing systemic risks, grouped in terms of their signaling properties (see Table 4): on the one hand, early-warning indicators that are relevant for the tightening phase of the CCyB by signaling - with a sufficient lead time - the materialization of systemic risks, and, on the other hand, stress indicators signaling financial or banking systemic stress in real time, allowing national authorities to respond promptly with the timely release of the CCyB.

\section{TABLE 4}

\section{CATEGORISATION OF INDICATIVE SUPPORTING INDICATORS IN TERMS OF THEIR SIGNALING PROPERTIES FOR THE CCYB}

\begin{tabular}{|l|l|}
\hline Early-warning indicators & Stress indicators \\
\hline Credit-to-GDP gap & LIBOR-OIS spreads \\
\hline $\begin{array}{l}\text { Commercial and residential real estate price-to- } \\
\text { income ratios, price gaps and growth rates }\end{array}$ & Average bank CDS premia \\
\hline $\begin{array}{l}\text { Real total credit growth, real bank credit growth } \\
\text { rates }\end{array}$ & Sovereign CDS premia \\
\hline $\begin{array}{l}\text { Deviation from trend of the deflated broad } \\
\text { monetary aggregate M3 }\end{array}$ & $\begin{array}{l}\text { ECB's CISS (Composite Indicator of Systemic } \\
\text { Stress })\end{array}$ \\
\hline Current account balances as a ratio to GDP & Ratio of non-performing loans to total gross loans \\
\hline Leverage Ratio & Merrill Lynch covered bond spread \\
\hline Debt Service-to-Income ratio & \\
\hline Real equity price growth & \\
\hline
\end{tabular}

Source: Author's elaboration based on Detken et al., 2014, p. 12.

Combining additional variables with the credit-to-GDP gap improves signaling performance in terms of the materialization of risks and reduces false alarms, compared with an isolated use of the credit-to-GDP gap (Detken, 2014, p. 54). The latter, although generally useful in the initial activation of the CCyB, does not appear to play a dominant role in the justification of national authority decisions on the CCyB rate notified to the ESRB (Arbatli-Saxegaard \& Muneer, 2020, p. 17). In practice, national authorities have resorted to their expert judgment using a set of supporting indicators. As a result, CCyB buffer rates in the EU/EEA countries have largely diverged from the buffer guide. ${ }^{9}$ Divergences may be explained by the fact that credit cycles are not always highly correlated, system vulnerabilities and their interactions differ between Member States, and different types of alternative macroprudential tools may not be available (such as those aimed at influencing lending standards - for example, through setting loan to value limits (LTV) and loan to income limits (LTI) to address household debt and potential risks from soaring housing prices) (Babić \& Fahr, 2019; Arbatli-Saxegaard \& Muneer, 2020; Buch, 2019; Babić, 2018).

More specifically, the number and type of additional indicators in national CCyB frameworks vary greatly across the EU/EEA (Pekanov \& Dierick, 2016, pp. 5-7). The total number of core indicators ranges between six (Spain) and 35 (Czech Republic) and, as a rule, at least one credit-related indicator is used along with a wider set of sectoral, market risk and macroeconomic indicators (Baba et al., 2020, p. 24). A 
few EU jurisdictions use heat maps, including Denmark, France, Italy and Spain, while others use a traffic light system (red/amber/green) based on thresholds (BCBS, 2017, p. 10). As in the case of the US, some EU/EEA countries (Austria, Bulgaria, Croatia, Finland, France, Luxembourg) have chosen not to publish or disclose the set of core indicators used in addition to the credit-to-GDP gap (Arbatli-Saxegaard \& Muneer, 2020, p. 21).

\section{THE EU MACROPRUDENTIAL POLICY RESPONSE TO THE COVID-19 PANDEMIC CRISIS}

Banks entered the COVID-19 pandemic crisis significantly better capitalized than at the onset of the GFC, having built up capital cushions for more than a decade. The euro area banking sector, on the whole, responded to the recent crisis with resilience based on the data available from the third quarter of 2020 (Enria, 2021).

As regards releasable capital buffers, the majority of EU/EEA Member States have never made active use of the $\mathrm{CCyB}$, opting to keep it at zero levels. A potential explanation may be that the CCyB is designed to be activated when excessive credit growth is associated with an increase in system-wide risk and most advanced countries have not come close to experiencing aggregate credit booms in the post-GFC period (Aikman, Haldane, Hinterschweiger \& Kapadia, 2018, p. 33). This said, the COVID-19 pandemic broke out at a time when more and more national authorities responsible for macroprudential supervision and policy around the world were starting to tighten their $\mathrm{CCyB}$ stance in line with the maximum twelve-month implementation lag.

Among EU/EEA countries, Norway and Sweden were the first to set positive CCyB rates, prompted mainly by concerns regarding household debt and housing prices, and subsequently adjusted their CCyB rates upwards, reaching $2.5 \%$ by early 2020 . Prior to the pandemic crisis, the UK was the only EU/EEA country to have drawn down its pre-announced CCyB rate (from $0.5 \%$ to $0 \%$ ), anticipating a prolonged period of heightened uncertainty following the result of the referendum on its withdrawal from the EU (Bank of England, 2016), and subsequently built it up again to $1 \%$ by January 2020.

In terms of CCyB levels, EU Member States had been active to varying degrees by end-2019. At that time, a tightening trend in the use of the $\mathrm{CCyB}$ was starting to emerge, as evidenced by pre-announced buffer rate increases in several EU/EEA jurisdictions, three of which were to activate the CCyB for the first time. Nine EU/EEA countries had set positive CCyB rates, six of which had announced the introduction of rates of 2 percentage points or higher.

In response to the sudden adverse shock of the COVID-19 pandemic, emergency macroprudential policy action took three forms: (i) gradual or full release of capital buffers (e.g. CCyB drawdowns); (ii) encouraging the use of static buffers such as the $\mathrm{CCoB}$ (i.e. that were not designed to be released, but can be used in periods of stress to absorb unexpected losses); and (iii) delayed introduction of structural and systemic-related buffers such as the O-SII buffer (IMF, 2020). These measures have not been justified on the basis of the known systemic risks that macroprudential tools have been intended to target, since the recent crisis originated from an adverse shock (a global health crisis) exogenous to the financial system. The overall objective of using capital buffers has been to ensure that the banking sector serves as a shock absorber in times of stress in order to mitigate procyclicality, rather than as a transmitter of risk to the financial system and the real economy. More specifically, the first widespread use of the CCyB was largely aimed at supporting bank lending and the broader financial sector, rather than to address systemic risks associated with excessive aggregate credit growth.

The BCBS urged banks to prioritize the use of capital resources to support the real economy and absorb losses, pointing out that a measured drawdown of banks' Basel III buffers to meet these objectives was both anticipated and appropriate in a period of stress and that sufficient time would be given to restore the buffers, taking account of economic and market conditions and individual bank circumstances (BIS, 2020).

The ECB, in particular, allowed banks under its supervision to operate temporarily below the level of capital defined by the $\mathrm{CCoB}$, fixed at $2.5 \%$ across Member States (ECB, 2020c). It later clarified that banks would not have to start replenishing capital buffers "before the peak in capital depletion is reached" (ECB, 2020b). Furthermore, it issued recommendations to all banks under its supervision to consider not 
distributing any cash dividends or conducting share buybacks, or to limit such distributions (ECB, 2020a). For its part, the ESRB (2021) recommended an exceptional extension of payout restrictions to account for uncertainty about future macroeconomic developments, as well as to ensure that all financial institutions that may pose a risk to financial stability maintain high levels of capital by asking competent authorities to request financial institutions to refrain from making distributions for the duration of the COVID-19 pandemic crisis.

\section{The Limited Role of the CCyB and the Constrained Usability of the CCoB in the EU/EEA}

The recent macroprudential policy response has highlighted the limited role played by the CCyB and the constrained usability of the CCoB to counter the pandemic's fallout. Up until the onset of the COVID19 pandemic crisis, most EU/EEA Member States demonstrated a general bias towards inaction, opting to set their CCyB rates at zero levels. In January 2020, less than half of Member States (twelve including the UK prior to its withdrawal from the EU) had activated their CCyB rates (see Table 5). Three EU Member States (Belgium, Germany and Luxembourg) had announced CCyB activation for the first time in the course of 2020 .

Being the only macroprudential buffer designed to be used countercyclically, the CCyB was a straightforward choice amidst the pandemic crisis. In early 2020, EU/EEA designated authorities swiftly drew down their CCyB rates, using the flexibility embedded in their CCyB frameworks to reduce/release the buffer rate at their discretion. Depending on their decisions, they may be divided into two categories: on the one hand, EU/EEA countries which fully released small initial buffer rates and, on the other hand, countries with higher buffer levels, built up before the crisis, which only partly reduced their CCyB rates (Arbatli-Saxegaard \& Muneer, 2020). Ultimately, CCyB releases and revoked increases took effect almost across the board. Only Luxembourg applied its pre-announced CCyB activation at $0.25 \%$ on 1 January 2020 and adjusted the rate upwards to $0.5 \%$ a year later (see Table 5).

TABLE 5

APPLICABLE CCYB RATES IN THE EU/EEA IN JANUARY 2020 AND JANUARY 2021

\begin{tabular}{|l|l|l|}
\hline Country & JANUARY 2020 & JANUARY 2021 \\
\hline Austria & $0 \%$ & $0 \%$ \\
\hline Belgium & $0 \%$ (pre-announced increase to 0.5\%) & $0 \%$ \\
\hline Bulgaria & $0.5 \%$ (pre-announced increase to $1 \%)$ & $0.5 \%$ \\
\hline Croatia & $0 \%$ & $0 \%$ \\
\hline Cyprus & $0 \%$ & $0 \%$ \\
\hline Czech Republic & $1.5 \%$ (pre-announced increase to 2\%) & $\mathbf{0 . 5 \%}$ \\
\hline Denmark & $1 \%$ pre-announced increase to 2\%) & $\mathbf{0 \%}$ \\
\hline Estonia & $0 \%$ & $0 \%$ \\
\hline Finland & $0 \%$ & $0 \%$ \\
\hline France & $0.25 \%$ (pre-announced increase to $0.5 \%)$ & $\mathbf{0 \%}$ \\
\hline Germany & $0 \%($ pre-announced increase to $0.25 \%)$ & $0 \%$ \\
\hline Greece & $0 \%$ & $0 \%$ \\
\hline Hungary & $0 \%$ & $0 \%$ \\
\hline Iceland & $2 \%$ & $\mathbf{0 \%}$ \\
\hline Ireland & $1 \%$ & $\mathbf{0 \%}$ \\
\hline Italy & $0 \%$ & $0 \%$ \\
\hline Latvia & $0 \%$ & $0 \%$ \\
\hline Liechtenstein & $0 \%$ & $0 \%$ \\
\hline Lithuania & $1 \%$ & $\mathbf{0 \%}$ \\
\hline Luxembourg & $0.25 \%$ (pre-announced increase to $0.5 \%)$ & $\mathbf{0 . 5 \%}$ \\
\hline Malta & $0 \%$ & $0 \%$ \\
\hline
\end{tabular}




\begin{tabular}{|l|l|l|}
\hline Netherlands & $0 \%$ & $0 \%$ \\
\hline Norway & $2.5 \%$ & $\mathbf{1 \%}$ \\
\hline Poland & $0 \%$ & $0 \%$ \\
\hline Portugal & $0 \%$ & $0 \%$ \\
\hline Romania & $0 \%$ & $0 \%$ \\
\hline Slovakia & $1.5 \%$ (pre-announced increase to 2\%) & $\mathbf{1 \%}$ \\
\hline Slovenia & $0 \%$ & $0 \%$ \\
\hline Spain & $0 \%$ & $0 \%$ \\
\hline Sweden & $2.5 \%$ & $\mathbf{0 \%}$ \\
\hline United Kingdom & $1 \%$ (pre-announced increase to $\%)$ & {$[\mathbf{0 \%}]$} \\
\hline
\end{tabular}

Source: Author's elaboration based on list of notified CCyB rates to the ESRB.

Notes: $\mathrm{CCyB}$ rates are calculated as a percentage of institutions' total risk exposure amount. Upwards/downwards adjusted rates (applicable in January 2021) are indicated in bold. The UK's January 2021 CCyB rate is indicated in square brackets given its withdrawal from the EU which took effect on 31 March 2020.

As a result of the lower $\mathrm{CCyB}$ accumulation prior to the pandemic, countercyclical capacity was limited. At end-2019, CCyB requirements accounted for a meagre share of only $0.2 \%$ of risk-weighted assets in the euro area banking sector as a whole, while non-releasable buffer requirements, comprising the CCoB, the Systemic Risk Buffer (SyRB) and buffers for systemically important institutions (G-SII and OSII buffers), stood at $3.4 \%$ of risk-weighted assets (de Guindos, 2021).

The recent experience with emergency macroprudential relaxation has thus highlighted the need for fully usable buffers. Banks must be both capable and willing to use the flexibility afforded by the buffer release and maintain buffers that they can draw upon for a long period, given that the materialization of pandemic-related losses will take time (Drehmann, Farag, Tarashev \& Tsatsaronis, 2020). Already, a host of studies have shown that having usable buffers provides banks with room to keep expanding and limits incentives for curtailing lending and/or tightening credit standards (Kanngieser, Martin, Moccero \& Maurin, 2019; Borsuk, Budnik \& Volk, 2020; Bordo, Duca \& Koch, 2016, as cited in Matyunina \& Ongena, 2020). Furthermore, banking sectors entering the COVID-19 crisis with strong buffers were found to be able to stage a quicker recovery if usable buffers can be channeled to the real economy (Lewrick, Schmieder, Sobrun \& Takáts, 2020). Yet banks show reticence and prefer to wait. Losses have been prevented or delayed and lending has been sustained thanks to extraordinary public support rather than prudential measures. After government loan guarantee schemes expire, banks forecast a substantial tightening of credit standards (Matyunina \& Ongena, 2020).

\section{Factors Inhibiting the Use of Capital Buffers}

A number of impediments have been identified as inhibiting the use of buffers in the current juncture. To date, the $\mathrm{CCoB}$ has not been used by EU/EEA banks as intended in a heightened risk environment. Despite the ECB's explicit encouragement for capital buffers to be used for lending purposes and loss absorption, preliminary evidence for the euro area (Behn, Rancoita \& Rodriguez d'Acri, 2020) suggests banks are reluctant to use non-releasable buffers such as the $\mathrm{CCoB}$ to absorb unexpected losses, mitigate negative externalities related to deleveraging, and prevent the imprudent depletion of capital. The latter objective is targeted by the post-GFC regulatory mechanism of automatic restrictions on banks' capital distributions and variable remunerations, which are associated with higher funding costs and may induce undesirable adjustment actions on the part of banks to avoid being constrained, i.e.: a) reducing the supply of credit primarily to corporate borrowers and, to a lesser extent, retail customers, b) reallocating loan portfolio towards safer assets with lower risk weights, and c) issuing new equity (Gropp, Mosk, Ongena \& Wix, 2019, as cited in Matyunina \& Ongena, 2020). In early 2020, capital targets announced by euro area banks were indeed ranging between $1 \%$ and $4 \%$ above the MDA trigger threshold (Andreeva, Bochmann \& Couailler, 2020, p. 4).

A review of relevant literature points to three types of impediments to the use of capital buffers. Firstly, the ability of banks to use their capital buffers stumbles upon potential stigma effects (Schmitz, Nellessen, 
Posch \& Strobl, 2021). On the one hand, a decision by a bank to draw down its capital buffers demonstrates a willingness to operate below the CBR, thus running the risk of triggering restrictions on capital distributions and management remuneration. On the other hand, a bank that eats into its capital buffers is perceived as falling short of market expectations in terms of its capital ratios (Behn, Rancoita \& Rodriguez d'Acri, 2020, p. 6).

Secondly, procyclical financial market pressures, which are more relevant in financial stress situations, also discourage buffer use. A potential breach of the CBR is seen as an adverse signal to the markets, given that it typically triggers automatic restrictions on capital distributions that affect shareholders and bank executives. Shareholders prefer dividend payments to be maintained, while bondholders may require banks to keep higher capital ratios to reduce default risk and hence the risk of coupon non-payment (Andreeva, Bochmann \& Couaillier, 2020). Anticipating negative market reactions, banks are unwilling to use buffers; not only do capital distribution restrictions affect their reputation, but also have the potential to lead to weakened prospective capitalization, which would lower their credit ratings over time (Schmitz, Nellessen, Posch \& Strobl, 2021). Rating downgrades linked to lower capital ratios and a higher default risk have a strong signaling effect to the markets. Hence, a downward spiral of lower bank capital levels and lower credit ratings could ultimately mean higher refinancing costs and limited access to funding.

A third type of impediment relates to uncertainty surrounding the replenishment of capital buffers. In particular, the ECB's announcement of prudential relaxation measures on 12 March (ECB, 2020c) was not followed by a clear timeline for the restoration of capital and liquidity buffers until 28 July (ECB, 2020b). Such uncertainty regarding the follow-up to potential buffer drawdowns explains at least partly the reluctance of euro area banks to use non-releasable buffers, as evidenced also by banks' public reports openly voicing concerns about the risk of a quick reintroduction of regulatory buffers (Andreeva, Bochmann \& Couaillier, 2020, p. 4-5). Replenishing capital buffers too early or too aggressively may weigh on credit supply and the economic recovery in a context of structurally weak profitability, when banks are vulnerable and the output gap is negative. Model simulations in fact suggest that a later and more gradual buffer replenishment will have a somewhat milder impact on GDP and lending, and under the adverse scenario of further deterioration of economic activity, buffer replenishment should not start before end2023 and must be phased in a commensurately slow manner (Budnik et al., 2020, p. 3).

Finally, a reason for banks to want to maintain their capital buffers is the reduced risk of supervisory scrutiny (Matyunina \& Ongena, 2020, p. 15). The strict prudential and supervisory requirements that EU banks are subject to may explain banks' cautious investment and lending behavior in the presence of heightened uncertainty. The closer to the regulatory minimum requirement banks operate, the greater their concerns about increased supervisory scrutiny. Changes in CBR and other regulatory requirements have a positive, strongly significant and economically large impact on banks' CET1 ratios, i.e. reductions in buffer requirements result in declining target ratios for banks (Andreeva, Bochmann \& Couaillier, 2020, p. 7). Nonetheless, there are signs that banks offset the expansionary effect of buffer releases by raising their target CET1 ratios when faced with worsening funding conditions and an expected economic slowdown (Andreeva, Bochmann \& Couaillier, 2020, p. 14). In light of the above, clear forward-looking supervisory guidance to remove any uncertainty about the duration of emergency measures, future recovery path and speed of buffer replenishment once conditions normalize is of utmost importance for the usability of buffers.

\section{Key Policy Suggestions in the Current Macroprudential Policy Debate}

The Policy Suggestion for a Larger Share of Releasable Buffers

Lately, several issues have come to prominence in the macroprudential policy debate. Policy suggestions to improve buffer usability have already been put forward, inter alia, on a larger share of releasable buffers and a default rate for the $\mathrm{CCyB}$ in a normal risk environment. In the EU, the opening of the macroprudential debate is all the more topical as the European Commission is setting in motion a review of the EU macroprudential framework (to be completed by 30 June 2022), which is a regular exercise to be repeated every five years in accordance with the provisions of Article $513 \mathrm{CRR}$, as amended by CRR2. 
An issue increasingly discussed around the world is creating macroprudential space in the prevailing "lower for longer" interest rate environment. In the EU, a policy suggestion relates to shifting the balance more towards releasable capital buffers such as the CCyB in the medium term (Schmitz, Nellessen, Posch $\&$ Strobl, 2021). This idea is founded on the premise that the limited build-up of releasable capital before the crisis has somewhat hampered the ability of Member State authorities to act countercyclically. In the current environment of very low, and even negative, interest rates where at least conventional monetary policy may be constrained by the zero lower bound, a releasable capital buffer can help dampen contractionary shocks and provide support to the bank lending channel of monetary policy (Darracq Pariès, Kok \& Rottner, 2020). The issue of integrating more releasability in capital requirements is particularly pertinent in light of the ongoing discussion on the complementarity of macroprudential policy to monetary policy, an issue on the agenda of the ECB's monetary policy strategy review. ${ }^{10}$ By enhancing countercyclical capacity, macroprudential policy can effectively complement monetary policy actions during a crisis, as the general consensus is against deploying monetary policy, at least in an activist way, for financial stability purposes given its limited efficacy and potential real-economy costs (Aikman, Haldane, Hinterschweiger \& Kapadia, 2018, p. 34).

As regards a more proactive use of the $\mathrm{CCyB}$, model-based simulations indicate that higher $\mathrm{CCyB}$ accumulation before the crisis could have supported the bank intermediation capacity during the crisis and rendered the effect of post-COVID macroprudential relaxation measures more forceful, as banks would have faced less stigma for consuming their buffers (Darracq Pariès, Kok \& Rottner, 2020). They suggest that if banks' pre-crisis countercyclical capacity had been higher, the likelihood of monetary policy being constrained by the effective lower bound would have been reduced.

Particular emphasis has been placed on enhancing countercyclical capacity without imposing new buffer requirements. The ECB's Vice-President Luis de Guindos (2021) recently affirmed that the CCoB would be a "natural candidate for creating macroprudential space" if it was made releasable in a capitalneutral manner, subject to strong governance and in line with Basel standards (de Guindos, 2021). The $\mathrm{CCyB}$ and the $\mathrm{CCoB}$ have already been under a comprehensive evaluation in terms of their implementation at international level as part of a broader evaluation and monitoring of the impact of post-GFC regulatory reforms in the banking sector (IMF, 2020; Araujo, Patnam, Popescu, Valencia, \& Weijia, 2020). Of course, any redesigning of the macroprudential policy framework remains on hold until the long-term effects of the still unfolding COVID-19 pandemic crisis become clear and the buffers' impact and efficiency are more thoroughly evaluated over a longer time period.

\section{The Issue of a Default CCyB in a Normal Risk Environment}

The idea of a default setting of the CCyB rate in a standard risk environment, i.e. when risks to financial stability are neither elevated nor subdued, has been aired in several BCBS jurisdictions prior to the COVID19 pandemic crisis. The framework originally proposed by the BCBS for the CCyB anticipated that, given its focus on excess aggregate credit growth, countries were "likely to only need to deploy the buffer on an infrequent basis" and banks were likely to "find themselves subject to a small buffer on a more frequent basis, since credit cycles are not always highly correlated across jurisdictions" (BCBS, 2011, p. 57). Hence, the prevailing approach in EU/EEA countries, among other jurisdictions, has been a zero CCyB rate by default, i.e. for most of the financial cycle.

A few countries, led by the UK, have nonetheless elaborated strategies on what they deem as a "neutral" rate when risk is at a tolerable, pre-determined level and the costs for banks are deemed appropriate in terms of having resilient and well-capitalized banks in a crisis (Babić, 2018, p. 74). This strategy is associated with their general approaches in favor of building up capital buffers before systemic vulnerabilities are heightened, reflecting their overall risk tolerance.

The UK's Financial Policy Committee (FPC) introduced a default rate that would be positive for a larger proportion of the financial cycle. Initially set in the range of 1\% (Bank of England, 2015), it was adjusted to 2\% in December 2019. The FPC defines a standard risk environment as one in which "borrowers will not tend to be unusually extended or fragile, asset prices are unlikely to show consistent signs of over, 
or under, valuation, and measures of risk appetite are likely to be in line with historical averages" (Bank of England, 2015, p. 16).

In the EU/EEA, four countries that entered the COVID-19 pandemic crisis with positive CCyB rates have been following an early activation strategy, partly to address existing or emerging risks in the real estate sector (Denmark, Ireland, Norway, and Sweden). Two EU Member States use a non-zero standard

rate approach: the central bank of Lithuania (Lietuvos bankas, 2017) aims at holding a base CCyB rate of at least $1 \%$ at "a good time" - when the expansion of the financial sector is neither too slow nor too fast. The Czech National Bank (CNB) also uses the standard rate concept, indicating in its rate-setting methodology that a rate of around $1 \%$ is needed when cyclical risks are at their usual level, expecting the standard rate to be reached within a two-year period after an activation decision (CNB, 2020, p. 11).

The debate has gained ground also outside the EU. In the US, there is a growing discussion on a dynamic resilience regime, including the need for a positive default $\mathrm{CCyB}$ in a standard risk environment (Kohn, 2020), while the Reserve Bank of Australia announced it is considering the introduction of a positive default level, having published a policy paper presenting a comparative analysis of the zero and positive default CCyB frameworks (Stojkov, 2020).

Given potential cross-border externalities and the possibility of regulatory arbitrage and avoidance opportunities, any reconsideration of EU macroprudential policy should be carefully designed. In view of the post-pandemic transition of the two capital buffers towards a more mature phase, the alteration of existing national frameworks can wait until after the crisis is over in order to take account of more empirical evidence of their use as well as best practices among BCBS jurisdictions.

\section{CONCLUSION}

Still in the early stages of their implementation, the CCyB and the CCoB provide banks with macroprudential space to absorb potential losses in different ways. On the one hand, the releasable, timevarying $\mathrm{CCyB}$ offers flexibility for policy and rate-setting decisions best suited to national circumstances, resulting in heterogeneous regimes and varying buffer levels across Europe. On the other hand, the nonreleasable $\mathrm{CCoB}$ aims to conserve banks' capital in line with a fixed percentage, set at the international level, which has been phased in fully in the EU/EEA since 2019.

The COVID-19 pandemic crisis has brought to light the limited role of the CCyB and the constrained usability of the $\mathrm{CCOB}$. To date, a general inaction bias regarding the $\mathrm{CCyB}$ has prevailed in the EU, despite a previously tightening trend that came to a sudden halt in the first months of 2020.

In the face of their first stress event (an adverse shock exogenous to the financial system), the two Basel III capital buffers were not used as initially intended. When the pandemic crisis hit, less than half of EU/EEA countries had positive CCyB levels. The widespread drawdowns of the CCyB in countries that had made active use thereof (at varying degrees) were aimed at supporting bank lending and avoiding an adverse feedback from the financial system to the real economy rather than addressing a build-up of systemwide risk associated with excessive credit growth. Furthermore, despite the ECB's explicit encouragement, banks have been somewhat reluctant to use the non-releasable CCoB and temporarily operate below the CBR, thus signaling their concerns about potential stigma effects and financial market reactions, with some also fearing increased supervisory scrutiny.

Even after the recent experience with macroprudential relaxation measures in response to the COVID19 pandemic crisis, the $\mathrm{CCyB}$ and the $\mathrm{CCoB}$ still remain largely untested with regard to their effectiveness as macroprudential instruments in both a standard and a heightened risk environment. In this respect, the still unfolding crisis provides a good opportunity for a debate on potential options to improve their use, impact and efficiency. Several policy suggestions have been aired in the EU, but also in other BCBS jurisdictions, and deserve to be further examined and discussed in light of the latest available research in view of the buffers' post-pandemic transition towards a more mature phase. 


\section{ENDNOTES}

1. The views expressed are those of the author and do not necessarily represent or reflect the views and policies of any institution the author is affiliated with.

2. Since 1 January 2020, macroprudential tools under the EU regulatory framework have also been applicable in EEA countries, i.e. Iceland, Liechtenstein and Norway.

3. The definition of credit should include all credit extended to households and other non-financial corporations in an economy independent of its form and the identity of the supplier of funds. This means that it should include credit extended by domestic and international banks as well as non-bank financial institutions either domestically or directly from abroad, and should also include all debt securities issued domestically or internationally to fund households and other non-financial private entities (including securitizations), regardless of who holds the securities.

4. The Hodrick-Prescott filter, a mathematical tool used in macroeconomics, assumes that the original series $\mathrm{y}_{t}$ can be divided into the trend (denoted as $\mathrm{g}_{t}$ ) and the gap (denoted as $\mathrm{c}_{t}$ ). For an analysis of the reasons underlying its use for generating credit gaps, see Couaillier \& Idier (2017) and Drehmann \& Yetman (2018).

5. Regulatory arbitrage in the financial sector is primarily aimed at minimizing the impact of regulation on a financial institution, by changing the structure but not the underlying substance of an activity. It typically entails leakage to differently regulated jurisdictions or differently regulated domestic sectors (e.g. non-banks operating outside the regulatory perimeter of a measure taken). See Constâncio (2019).

6. The 'level playing field' debate centers on the need to coordinate financial regulation on an international basis in order to ensure that the application of more stringent rules in one jurisdiction will not result in the shifting of activities to less regulated jurisdictions. EU legislators have placed particular emphasis on the need to create equal conditions of competition in the Single Market for financial services, by clearly allocating regulatory/supervisory competences between home and host Member States.

7. Although the Basel III standards on capital buffers were proposed to apply only to "internationally active banks" (BCBS, 2011, p. 57), the EU capital requirements regime has been extended to all "institutions" (i.e. credit institutions and certain types of investment firms), as defined in Article 4(1)(3) of Regulation (EU) No 575/2013 (Capital Requirements Regulation - CRR). Under this Article, a credit institution means "an undertaking the business of which is to take deposits or other repayable funds from the public and to grant credits for its own account". The motivation behind this extended scope is that the playing field can be kept level by applying macroprudential measures broadly across the financial system.

8. The ECB has been assigned specific tasks relating to the prudential supervision of banks within the Single Supervisory Mechanism (SSM), i.e. the first pillar of the Banking Union, by virtue of Council Regulation (EU) No 1024/2013. The Member States covered by the SSM are the countries whose currency is the euro (euro area countries), as well as Bulgaria and Croatia, two non-euro area countries which have established a close cooperation with the ECB since 1 October 2020.

9. Five key weaknesses of the buffer guide are identified in a recent IMF study (Baba et al., 2020, pp. 5-8): excessive credit vs. financial deepening, countercyclicality, large credit booms in the past, general problems with HP filters, and a lack of sectoral detail, the analysis of which goes beyond the scope of this paper.

10. In January 2020, the ECB launched the review of its monetary policy strategy, deemed necessary in an environment of historically low interest rates, limits to lowering interest rates, and new challenges to the economy arising from globalization, digitalization, an ongoing ageing population and climate change.

\section{REFERENCES}

Aikman, D., Haldane, A., Hinterschweiger, M., \& Kapadia, S. (2018). Rethinking financial stability. Bank of England Staff Working Paper, No 712.

Aikman, D., Haldane, A., \& Kapadia, S. (2013). Operationalising a macroprudential regime: Goals, tools and open issues. Bank of Spain Financial Stability Journal, 24, 10-30.

Andreeva, D., Bochmann, P., \& Couaillier, C. (2020). Financial market pressure as an impediment to the usability of regulatory capital buffers. ECB Macroprudential Bulletin, 11 .

Araujo, D.J., Patnam, M., Popescu, A., Valencia, F., \& Weijia, Y. (2020). Effects of Macroprudential Policy: Evidence from Over 6,000 Estimates. IMF Working Papers, No 20/67. 
Arbatli-Saxegaard, E.C., \& Muneer, M.A. (2020). The countercyclical capital buffer: A cross-country overview of policy frameworks. Norges Bank Staff Memo, No 6/2020.

Baba, C., Dell'Erba, S., Detragiache, E., Harrison, O., Mineshima, A., Musayev, A., \& Shahmoradi, A. (2020). How Should Credit Gaps Be Measured? An Application to European Countries. IMF Working Papers, No 20/6.

Babić, D. (2018). Special feature B: Use of the countercyclical capital buffer - A cross-country comparative analysis. A Review of Macroprudential Policy in the EU in 2017. European Systemic Risk Board.

Babić, D., \& Fahr, S. (2019). Shelter from the storm: recent countercyclical capital buffer (CCyB) decisions. ECB Macroprudential Bulletin, 7.

Bank of England. (2016, July). Financial Stability Report, No 39.

Bank of England. (2015, December). The framework of capital requirements for UK banks. Supplement to the Financial Stability Report.

Bank of England. (2009, November). The role of macroprudential policy. Discussion paper.

BCBS. (2017, June). Range of practices in implementing the countercyclical capital buffer policy. Bank for International Settlements.

BCBS. (2011, June). Basel III: 'A global regulatory framework for more resilient banks and banking systems (revised version). Bank for International Settlements.

BCBS. (2010, December). Guidance for national authorities operating the countercyclical capital buffer. Bank for International Settlements.

BCBS (2006, June). Basel II International Convergence of Capital Measurement and Capital Standards: A Revised Framework (comprehensive version). Bank for International Settlements.

Behn, M., Rancoita, E., \& Rodriguez d'Acri, C. (2020). Macroprudential capital buffers - objectives and usability. ECB Macroprudential Bulletin, 11 .

BIS. (2020, June 17). Basel Committee meets; discusses impact of Covid-19; reiterates guidance on buffers. Press Release.

BIS. (2018, June). BIS Annual Economic Report 2018. IV. Moving forward with macroprudential frameworks. Bank for International Settlements.

Borsuk, M., Budnik, K., \& Volk, M. (2020). Buffer use and lending impact. ECB Macroprudential Bulletin, 10 .

Buch, C. (2019, November 1). Macroprudential Policy in Europe: The German Countercyclical Capital Buffer $(C C y B)$. Panel Statement at the Bank of Mexico Seminar "Financial Stability and Central Banks", Mexico City. Retrieved from https:/www.bundesbank.de/en/press/speeches/macroprudential-policy-in-europe-the-germancountercyclical-capital-buffer-ccyb--813152\#tar-5.

Budnik, K., Darracq Pariès, M., Kok, C., Lang, J.H., Lo Duca, M., Rancoita, E., . . Rottner, M. (2020, November). A macroprudential perspective on replenishing capital buffers. ECB Financial Stability Review.

Committee on the Global Financial System (2010). Macroprudential instruments and frameworks: A stocktaking of issues and experiences. Report submitted by the Committee on the Global Financial System overseen by a Coordinating Group chaired by Lex Hoogduin of The Netherlands Bank. CGFS Papers, No 38.

Constâncio, V. (Ed.). (2019). Macroprudential policy at the ECB: Institutional framework, strategy, analytical tools and policies. ECB Occasional Paper Series, No 227.

Couaillier, C., \& Idier, J. (2017). Measuring excess credit using the 'Basel gap': relevance for setting the countercyclical capital buffer and limitations. Quarterly Selection of Articles - Bulletin de la Banque de France, 46, 5-18.

Council Regulation (EU) No 1024/2013 of 15 October 2013 conferring specific tasks on the European Central Bank concerning policies relating to the prudential supervision of credit institutions. Official Journal, L 287, 29.10.2013, 63-89. 
Crockett, A. (2000, September 20-21). Marrying the micro- and macro-prudential dimensions of financial stability. Remarks before the "Eleventh International Conference of Banking Supervisor". Basel.

Darracq Pariès, M., Kok, C., \& Rottner, M. (2020). Enhancing macroprudential space when interest rates are low for long. ECB Macroprudential Bulletin, 11.

De Guindos, L. (2021, March 1). Is macroprudential policy resilient to the pandemic? Panel contribution at the Banque de France / Sciences Po Financial Stability Review Conference 2021. Retrieved from https://www.ecb.europa.eu/press/key/date/2021/html/ecb.sp210301 207a2ecf7e.en.html.

Detken, C., Weeken, O., Alessi, L., Bonfim, D., Boucinha, M.M., Castro, C., . . Welz, P. (2014). Operationalising the countercyclical capital buffer: indicator selection, threshold identification and calibration options. ESRB Occasional Paper Series, No 5.

Deutsche Bundesbank. (2015, November). The countercyclical capital buffer in Germany - Analytical framework for the assessment of an appropriate domestic buffer rate.

Directive (EU) 2019/878 of the European Parliament and of the Council of 20 May 2019 amending Directive 2013/36/EU as regards exempted entities, financial holding companies, mixed financial holding companies, remuneration, supervisory measures and powers and capital conservation measures (2019, May 20). Official Journal, L 150, 7.6.2019, 253-295.

Directive 2013/36/EU of the European Parliament and of the Council of 26 June 2013 on access to the activity of credit institutions and the prudential supervision of credit institutions and investment firms (2013, June 26). Official Journal, L 176, 27.6.2013, 338-436.

Drehmann, M., Borio, C., \& Tsatsaronis, K. (2011). Anchoring Countercyclical Capital Buffers: The role of Credit Aggregates. International Journal of Central Banking, 7(4), 189-240.

Drehmann, M., Farag, M., Tarashev, N., \& Tsatsaronis, K. (2020, April). Buffering Covid-19 losses The role of prudential policy. BIS Bulletin, No 9. Bank for International Settlements.

Drehmann, M., \& Yetman, J. (2018). Why you should use the Hodrick-Prescott filter - at least to generate credit gaps. BIS Working Paper, No 744.

ECB. (2020a). Recommendation ECB/2020/62 of the European Central Bank of 15 December 2020 on dividend distributions during the COVID-19 pandemic and repealing Recommendation ECB/2020/35. Official Journal, C 437, 1-3.

ECB. (2020b, July 28). ECB extends recommendation not to pay dividends until January 2021 and clarifies timeline to restore buffers. Press release.

ECB. (2020c, March 12). ECB Banking Supervision provides temporary capital and operational relief in reaction to coronavirus. Press release.

ECB (2009, December). Is Basel procyclical? A selected review of the literature. Financial Stability Review, 143-150.

Edge, R.M., \& Liang, N. (2020). Stronger financial stability governance leads to greater use of the countercyclical capital buffer. Brookings Institution Working Papers, No 56.

Enria, A. (2021, March 16). European banks in the post-COVID-19 world. Speech at the Morgan Stanley Virtual European Financials Conference. Frankfurt am Main. Retrieved from https://www.bankingsupervision.europa.eu/press/speeches/date/2021/html/ssm.sp210316 55c333 2593.en.html?utm_source=ecb_twitter\&utm_medium=social\&utm_campaign=210316_speech_A $\mathrm{E}$

ESRB. (2021). Recommendation ESRB/2020/15 on restriction of distributions during the COVID-19 pandemic amending Recommendation ESRB/2020/7 on restriction of distributions during the COVID-19 pandemic. Official Journal C 27, 25.1.2021, 1-4.

ESRB. (2017, August). List of national macroprudential authorities and national designated authorities in EU Member States. European Systemic Risk Board.

ESRB. (2015, August). The ESRB Handbook on operationalising macroprudential policy in the banking sector. European Systemic Risk Board.

ESRB. (2014, March). Flagship report on Macroprudential Policy in the Banking Sector. European Systemic Risk Board. 
Finansinspektionen. (2014). Regulations regarding the countercyclical buffer rate, 8 September 2014. Decision Memorandum FI Ref. 14-7010.

Goodhart, C.A.E. (2009). Procyclicality and Financial Regulation. Bank of Spain Financial Stability Journal, 16, 9-20.

Goodhart, C.A.E., \& Segoviano, M.A. (2004). Basel and procyclicality: a comparison of the standardised and IRB approaches to an improved credit risk method. London School of Economics Financial Markets Group Discussion Paper, No 524.

Heid, F. (2007). The Cyclical Effects of the Basel II Capital Requirements. Journal of Banking and Finance, 31(12), 3885-3900.

Hernández de Cos, P. (2019, October 1). Post-Basel III: time for evaluation. Keynote address at the 14th ASBA-BCBS-FSI High-level Meeting on Global and Regional Supervisory Priorities. Lima.

IMF. (2020, September). Main Operational Aspects for Macroprudential Policy Relaxation. Covid-19 Special Notes. Retrieved from https://www.imf.org/ /media/Files/Publications/covid19-specialnotes/en-special-series-on-covid-19-main-operational-aspects-for-macroprudential-policyrelaxation.ashx?la=en

IMF. (2009, April). Responding to the financial crisis and measuring systemic risks. IMF Global Financial Stability Report. Retrieved from https://www.imf.org/en/Publications/GFSR/Issues/2016/12/31/Responding-to-the-FinancialCrisis-and-Measuring-Systemic-Risks

IMF-FSB-BIS. (2016, August). Elements of Effective Macroprudential Policies. Lessons from International Experience. Report to the G20. Retrieved from https://www.imf.org/external/np/g20/pdf/2016/083116.pdf

Kanngiesser, D., Martin, R., Moccero, D., \& Maurin, L. (2019). The macroeconomic impact of shocks to bank capital buffers in the euro area. The B.E. Journal of Macroeconomics, 20(1). https://doi.org/10.1515/bejm-2018-0009

Kohn, D. (2020, June 12). COVID-19 and the banks. Brookings Institution Report. Retrieved from https://www.brookings.edu/research/covid-19-and-the-banks/.

Lewrick, U., Schmieder, C., Sobrun, J., \& Takáts, E. (2020, May). Releasing bank buffers to cushion the crisis - A quantitative assessment. BIS Bulletin, No 11. Bank for International Settlements.

Lietuvos Bankas. (2017, December 21). With an upswing in credit and housing markets, banks will have to accumulate more capital. Press Release. Retrieved from https://www.lb.lt/en/news/with-anupswing-in-credit-and-housing-markets-banks-will-have-to-accumulate-more-capital

Magyar Nemzeti Bank. (2016). Methodology underlying the determination of the benchmark countercyclical capital buffer rate and supplementary indicators signaling the build-up of cyclical systemic financial risk. Retrieved from https://www.mnb.hu/letoltes/ccyb-methodologynew-en-1.pdf

Matyunina, A., \& Ongena, S. (2020). Has the relaxation of capital and liquidity buffers worked in practice? European Parliament Economic Governance Support Unit Report, PE 651.374. Retrieved from https://www.europarl.europa.eu/RegData/etudes/IDAN/2020/651374/IPOL_IDA(2020)651374_E N.pdf

Norges Bank. (2021). Advice on the countercyclical capital buffer 2021 Q1. Retrieved from https://www.norges-bank.no/en/news-events/news-publications/Submissions/2021/2021-03-17$\mathrm{ccb} /$

Pekanov, A., \& Dierick, F. (2016, December). Implementation of the countercyclical capital buffer regime in the European Union. ESRB Macroprudential Commentaries, 8. European Systemic Risk Board.

Recommendation ESRB/2011/3 of the European Systemic Risk Board of 22 December 2011 on the macro-prudential mandate of national authorities (2011, December 22). Official Journal, C 41, 14.2.2012, 1-4. 
Regulation (EU) 2019/876 of the European Parliament and of the Council of 7 June 2019 amending Regulation (EU) No 575/2013 as regards the leverage ratio, the net stable funding ratio, requirements for own funds and eligible liabilities, counterparty credit risk, market risk, exposures to central counterparties, exposures to collective investment undertakings, large exposures, reporting and disclosure requirements, and Regulation (EU) No 648/2012 (2019, June 7). Official Journal, L 150, 7.6.2019, 1-225.

Regulation (EU) No 575/2013 of the European Parliament and of the Council of 26 June 2013 on prudential requirements for credit institutions and investment firms and amending Regulation (EU) No 648/2012 (2013, June 26). Official Journal, L 176, 27.6.2013, 1-337.

Schammo, P. (2019). Inaction in Macroprudential Supervision: Assessing the EU's Response. Journal of Financial Regulation, 5, 1-28.

Schmitz, S., Nellessen, V., Posch, M., \& Strobl, P. (2021, January). Buffer usability and potential stigma effects. SUERF Policy Note, No 219.

Schroth, J. (2021). Macroprudential policy with capital buffers. Journal of Monetary Economics, 118(C), 296-311. doi:10.1016/j.jmoneco.2020.12.003.

Stojkov, K. (2020, September). Different approaches to implementing a countercyclical capital buffer. Reserve Bank of Australia Bulletin, pp. 113-121.

Stremmel, H. (2015). Capturing the financial cycle in Europe. ECB Working Paper Series, No 1811. 